Oral Section

\title{
Evaluation of homeopathic and biotherapic treatments in a swine farm to control Escherichia coli infection: a long term study
}

\author{
Cidéli de Paula Coelho1,2,5, Francisco Rafael Martins Soto ${ }^{3}$, \\ Erlete Rosalina Vuaden ${ }^{4}$, Priscilla Anne Melville ${ }^{1}$, \\ Andrea Micke Moreno ${ }^{1}$, Leoni Villano Bonamin²,5, Nilson Roberti Benites ${ }^{1}$ \\ ${ }^{1}$ College of Veterinary Medicine and Animal Sciences, University of Sao Paulo, Brazil, \\ 2Faculty of Veterinary Medicine, Paulista University (UNIP), Brazil \\ ${ }^{3}$ Federal Institute of Education, Science and Technology of São Paulo, Brazil \\ ${ }^{4} \mathrm{M}$ Cassab- Animal Technology, Brazil \\ 5Santo Amaro University (UNISA), Brazil
}

\begin{abstract}
Background: Escherichia coli is the most important etiological agent in neonatal diarrhea in swine, and Enterotoxigenic Escherichia coli (ETEC) is the most commonly isolated. Regarding to virulence factors, five main types of fimbriae were already described in swine samples: F4 (K88), F5 (K99), F6 (987P), F18 and F41. Thermolabile (LT) and thermostable enterotoxins (ST), as well as shiga-like toxin or verotoxin (Stx2) are also found in isolates of swine origin, related to diarrhoea process.
\end{abstract}

Methods: This long term study has been developed in a swine farm (Mato Grosso, Brazil), in which 93 piglets were studied and 184 fecal samples were evaluated in two steps, with the aim to search the presence of Escherichia coli and to prepare a specific biotherapic medicine. Each step had one year of interval each other. Concurrently, for each step, a detailed anamnesis was made for choosing the ideal homeopathic medication for each step (Phosphorus $30 \mathrm{CH}$ and Pulsatilla $30 \mathrm{CH}$, respectively). In each step, four groups consisting of 11-12 piglets and the respective primiparous mother pig were formed, and the treatments happened simultaneously: control group (antimicrobial treatment, the same used in the swine farm), homeopathic medication, E. coli biotherapic and homeopathic medication associated to biotherapic. The medications were made according to the Brazilian Homeopathic Pharmacopeia and the treatment lasted 12 days. After 24 days, in the weaning, the weight gain of each bath was also evaluated. Considering both steps, the research of virulence factors and enterotoxins was carried out in 99 Escherichia coli colonies through Polymerase Chain Reaction - PCR.

Results: In both steps, the homeopathy treated groups passed from $75.0 \%$ of diarrhea incidence to $8.3 \%$ at the end of the treatment $(\mathrm{p}<0.05)$; the groups treated with homeopathy + biotherapic also presented significant reduction in the number of sick animals ( $p<0.05$ ), passing from $68.2 \%$ to $27.2 \%$ at the end. Weight 
gain in all groups taking homeopathic medicines was 15\% higher than the control group. Only the F41 virulence factor was found in $10.0 \%$ of the studied animals.

Conclusion: Homeopathic medications seem to be an efficient alternative for controlling enteric disorders in swine, increasing the weight gain. However, further studies should be conducted to confirm if homeopathic medicines can interfere in the presence of virulence factors and enterotoxins in bacterial population.

Keywords: Biotherapic. Escherichia coli. Homeopathy. PCR. Swine.

Table 1 - Number of animals with diarrhea at the beginning and the end of treatment.

\begin{tabular}{|l|c|c|}
\hline \multicolumn{1}{|c|}{ Group } & $\begin{array}{c}\text { Beginning (number of sick } \\
\text { animals) (\%) }\end{array}$ & $\begin{array}{c}\text { End (number of sick } \\
\text { animals) (\%) }\end{array}$ \\
\hline E. coli biotherapic 30 CH & $9(37,5 \%)$ & $0(0 \%)^{*}$ \\
\hline $\begin{array}{l}\text { Homeopathic medication + } \\
\text { biotherapic 30 CH }\end{array}$ & $15(68,2 \%)$ & $6(27,2 \%)^{*}$ \\
\hline Homeopathic medication 30 CH & $18(75,0 \%)$ & $2(8,3 \%)^{*}$ \\
\hline Control group & $10(43,5 \%)$ & $4(19,0 \%)$ \\
\hline Total number of animals & 93 & 91 \\
\hline
\end{tabular}

* Fischer's test $\mathrm{p}<0,05$ regarding the first day.

Table 2 - Weight average at the beginning of treatment and weaninging.

\begin{tabular}{|l|c|c|c|}
\hline \multicolumn{1}{|c|}{ Group } & $\begin{array}{c}\text { Beginning } \\
\text { (Average weight/ } \\
\text { number of } \\
\text { animals) }\end{array}$ & $\begin{array}{c}\text { Weaning (Average } \\
\text { weight/ number of } \\
\text { animals) }\end{array}$ & $\begin{array}{c}\text { Average weight } \\
\text { again }\end{array}$ \\
\hline E. coli biotherapic 30 CH & $1525(24)$ & $6227(21)$ & 4702 \\
\hline $\begin{array}{l}\text { Homeopathic medication+ } \\
\text { biotherapic 30 CH }\end{array}$ & $1236(22)$ & $5945(21)$ & 4709 \\
\hline Homeopathic medication 30 CH & $1625(24)$ & $6156(21)$ & 4531 \\
\hline Control group & $1434(23)$ & $5449(20)$ & 4015 \\
\hline Total number of animals & 93 & 83 & \\
\hline
\end{tabular}

\section{(c)) EY-NC-ND Licensed to GIRI}

Support: authors declare that this study received no funding

Conflict of interest: authors declare there is no conflict of interest

Correspondence author: Cidéli de Paula Coelho, ccideli@uol.com.br

Received: 01 June 2012; Revised: 09 August 2012; Published: 30 September 2012.

How to cite this article: Coelho CP, Soto FRM, Vuaden ER, Melville PA, Moreno AM, Bonamin LV, Benites NR. Evaluation of homeopathic and biotherapic treatments in a swine farm to control Escherichia coli infection: a long term study. Int J High Dilution Res [online]. 2012 [cited YYYY Month dd]; 11(40):136-137. Proceedings of the XXVI GIRI Symposium; 2012 Sep 20-22; Florence (Italy). GIRI; 2012; Available from: http://www.feg.unesp.br/ ojs/index.php/ijhdr/article/view/587/590 